\title{
ON THE ISSUE OF RW MANAGEMENT EFFICIENCY
}

\author{
Samoylov A. A., Ilyasov D. F. \\ Nuclear Safety Institute of the Russia Academy of Sciences, Moscow, Russia
}

Article received on July 30, 2019

\begin{abstract}
Changes in RW management practice that occurred under new conditions established following the enactment of the Federal Law "On RW Management" [1] have prompted the efforts on finding the main issues, as well as choosing the best ways to solve them. So far, this task has been addressed in particular practical areas to improve the efficiency of particular RW management stages. At the same time, due to technological interrelation at different RW management stages, balanced decisions on issues having conflicting effects on several RW management stages at once are to be made. Under holistic approach, it seems essential to form a criterion indicating the efficiency of the system in general taking into account all RW management stages. The article is focused on the development of solutions enabling to evaluate the efficiency of the Unified State System (USS) for RW management with due account of the technological interrelations at different RW management stages.
\end{abstract}

Keywords: radioactive waste ( $R W$ ), stages of $R W$ management, the USS RW efficiency.

\section{Introduction}

Implementation of any activity suggests that sooner or later the question arises regarding its effectiveness and potential way for its improvement. Basically, efficiency is seen as a ratio between the cost associated with the implemented activity and the result achieved. Under its simplest form, this is the "result-cost" ratio, which is widely used in comparative analysis of various technologies applied in the production of marketable products.

Similar approach is difficult to apply when it comes to the effectiveness of some complex system, such as the Unified State System for Radioactive Waste Management (hereinafter referred to as USS RW), which is now being developed. The main reason for that is the uncertainty about what should be meant by the result of relevant activities. The nontriviality of this issue is primarily explained by the wide range of RW characteristics managed within the USS RW, as well as by different time scales of activities associated with the management of various RW types. In addition to economic aspects, safety, including the long-term one, is also seen as a relevant aspect for RW management.

Given significant differences between the categories of waste managed within the USS RW, it seems reasonable that prior to such performance assessment homogeneous waste streams are to be identified. Then, at the first stage, it would be possible to evaluate the effectiveness of activities with respect to a particular RW stream (reciprocal of the waste management cost for a given RW stream). At the second stage, by applying the values of efficiency for homogeneous RW streams, one should determine the total performance of the entire system. Actually, this can be done by averaging these estimates taking into account the differences in the characteristics of RW pertaining to different waste streams. 
The task of averaging the efficiencies can be solved similarly to the problem of determining the average based on the measurements with different accuracy. Under such setting, during the statistical processing of measurements, averaging is carried out using weight coefficients for each measurement result. These coefficients specify the "degree of confidence" in the results obtained (determined based on the error of the measurement result). The weight coefficients applied to calculate the average performance should account for the important role of a homogeneous RW stream in achieving the goals stated under the USS RW.

Approach to determine the efficiency of activities involving a homogeneous stream under USS RW

As noted above, the main problem refers to the development of an approach enabling to specify the "result of activities" implemented under USS RW. Given the wordings provided in the provisions of the law [1], a list of features determining the effectiveness of its activities, can be compiled. Binding nature of retrievable RW disposal (Article 12, Part 1) is seen as the main principle suggested by its provisions. In general, this principle can be extended to non-retrievable RW as well, since the facilities holding such waste are required to be upgraded to RW disposal facilities or RW conservation facilities (the latter is seen as an intermediate point between the facility holding the waste and a disposal facility) (Article 24, Part 3).

Based on the above, disposal of waste can be considered as a result of USS RW activities with respect to a RW stream, which requires the fulfillment of the following two conditions:

1) RW stream should be covered by the financial provisions of the USS RW. It means that relevant mechanism should be provided for to ensure the availability of financial resources to ensure a full cycle of waste management, including disposal and monitoring. It is assumed that for RW accumulated before 2011, this issue was resolved by assigning the waste to federally owned property.

2) Appropriate technologies should be available for the RW stream ensuring proper level of safety at all waste management stages.

Therefore, the following equation can be used to calculate USS RW performance indicator with respect to a certain waste stream:

$$
E=\sum_{i} \frac{K_{\text {opz-фин }}^{i} \cdot K_{\text {mехн }}^{i}}{S_{\Sigma}^{i}},
$$

Where $K_{\text {ор- }- \text { фин }}^{i}$ is the coefficient of inclusion for the $i$-th RW stream into the financial model; $K_{\text {mexн }}^{i}$ is the coefficient demonstrating the coverage of the $i$-th RW stream by engineering solutions (technologies, infrastructure) designed for the RW management, including waste storage and disposal; $S_{i}$ stands for the total costs associated with the implementation of the full RW management cycle for the $i$-th RW stream, including storage and disposal.

Obviously, to achieve maximum performance with respect to a specific waste stream, financial and technological support of the full RW management cycle is required, while the total cost associated with the implementation of all RW management stages, including disposal, should be kept minimal.

It should be emphasized that apart from RW itself considered immediately as a USS RW object, the performance of the system is also influenced by the management of contaminated materials, which is already outside the scope of the USS RW activities. According to the definition, RW involves materials that are not subject to any further use [2]. Consequently, if radioactively contaminated materials are excluded from the RW category due to their involvement in economic activity, then given the reduced cost of their management, the USS RW effectiveness increases. For this reason, in this article the term "contaminated materials" will be sometimes used along with the term RW.

\section{Approach enabling to determine USS RW effectiveness}

Weighting coefficients based on which averaging (or convolution) of the management efficiencies with regard to individual RW streams is to be carried out should be determined to enable a holistic assessment of USS RW performance. Various quantities can be considered as such weighting coefficients: RW volume/mass or its activity. However, the use of any of these quantities encounters a number of contradictions. It is obvious that same volume or mass of RW with different activities will be associated with different level of hazard posed to personnel and the public. It is similar for RW having same activity, but characterized with different resistance to external influences or natural degradation of RW packaging materials. As part of nuclear legacy waste inventory taking [3], approaches allowing to rank the facilities according to the potential hazards posed to personnel, public and the environment were suggested. One of the proposed ranking tools (comprehensive indicator $(C \Pi)$ of the potential hazard posed by nuclear facilities) was further developed in $[4,5]$. Which is specific for this indicator is that in addition to the actual activity of the facility, it also takes into account the stability and reliability of contaminated materials characteristics, as well as the availability of engineered 
safety barriers for nuclear and radiation safety and their robustness and reliability.

To assess the efficiency of RW management activities, a similar indicator was proposed as a weighting coefficient. The indicator is derived based the characteristics of the waste belonging to the waste stream in question. Unlike $C \Pi$, it excludes the parameters defining the characteristics of the storage facilities rather than those of the radioactive waste. In this case, the efficiency weighting coefficient specified for an individual waste stream can be calculated using the following equation:

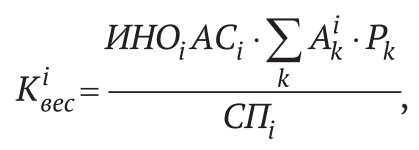

where $И Н O_{i}$ stands for the "Waste Uncertainty Identifier" parameter indicating the state of materials containing radionuclides, including the availability of managerial and technical measures to monitor their state for the $i$-th radioactive waste stream; $A C_{i}$ is the parameter accounting for the aggregate state of materials containing radionuclides of the $i$-th RW stream;

$\mathrm{A}_{k}^{i}$ is the activity of the $k$-th radionuclide in the $i$-th RW stream;

$P_{k}$ accounts for the relative radiological hazard potential for the $k$-th radionuclide (table value); $C \Pi_{i}$ is the parameter indicating the stability state of materials containing radionuclides.

Below is provided a brief overview of parameters used to determine the efficiency weighted coefficients for individual RW streams. For more details on the procedure used to identify the corresponding parameters please refer to [5].

ИНО parameter characterizes the condition of materials with relevant numerical values varying in the range from 2 to 100: the more dangerous is the state of the materials containing radionuclides, the higher is the value of the parameter. The criteria used to specify this parameter involve the following:

- exposure to physical degradation of materials containing radionuclides;

- presence of a packaging confining the materials containing radionuclides;

- availability of data on the characteristics of materials;

- monitoring of ongoing processes.

$A C$ parameter specifies the aggregate state of materials and varies over a wide range of values depending on the ability of materials to spread into the environment. It is obvious that the most mobile are materials in a liquid and gaseous state as they can escape beyond packaging materials completely, least mobile are monolithic solids.
СП parameter accounts for the frequency of control arrangements over the materials' state. The value of this parameter grows along with the increase in the length of the period within which it's deemed that the safety is to be ensured. $C \Pi$ values vary in a wide range from 1 (waste requiring continuous cooling, ventilation, etc.) to $10^{4}$ (immobilized waste form packaged into containers or waste held in the facilities for non-retrievable RW with relevant demonstrations of the long-term safety being provided).

The final expression for USS RW performance indicator can be as follows:

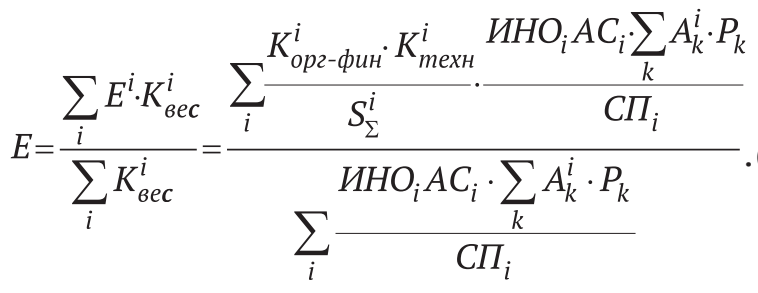

It should be noted that the efficiency functional identified as above lies in the domain of non-negative values.

\section{Testing the performance assessment methodology through the example of individual RW streams and measures to enhance USS RW}

Let us consider some examples of measures aimed at optimizing RW management with reference to their influence on its effectiveness using the above approach. [6] presents a list of challenging issues in RW management, as well as the main ways allowing to address them. Based on the proposed approach for performance indicator assessment, below are evaluated some potential effects caused by a number of situations. The following measures aimed at increasing USS RW performance were considered:

1. Establishment of a mechanism enabling the funding of activities associated with the upgrading of facilities holding non-retrievable RW to RW conservation or disposal facilities as part of newly emplaced RW (for example, facility 651/1 of FSUE MCC);

2. Segregation operations introduced at the stage of accumulated RW retrieval to reduce the costs of waste processing and disposal (the case study of ILW storage facility at Beloyarsk NPP);

3 . The use of contaminated materials in the construction of EBS during remediation efforts performed at LRW storage reservoirs (the case study of V-17 reservoir at FSUE PA Mayak);

4. Reducing the disposal cost for graphite waste by constructing a purpose-designed RWDF at a depth of $100 \mathrm{~m}$. 
To calculate the impact of the above measures on USS RW performance, a number of assumptions should be made on the cost of complete RW management flow chart and on how this cost can change due to the implementation of relevant measures.

When considering the impact of measure \#1 on the effectiveness of RW management activities, we proceeded from a total cost of $\sim 1$ billion rubles per facility in question (estimated in accordance with [7]). At the same time, it was assumed that the cost needed to upgrade a facility holding nonretrievable waste was distributed proportionally to the breakdown of the RW inventory between newly placed and accumulated RW, and the volume of additionally placed RW accounted for $1 \%$ of the accumulated RW inventory.

When considering activity \#2, we proceeded from previously performed estimates of accumulated RW, which, according to the results of radiation monitoring, can be excluded from this category [8]. RW management cost prior to RW disposal was taken equal to $\sim 0.4$ of the total RW management cost (according to the averaged data presented in local strategies for RW management at NPPs).

When considering activity \#3, we proceeded from the use of $\sim 50,000 \mathrm{~m}^{3}$ of contaminated crushed concrete structures generated as the result of nuclear legacy decommissioning. This material will be used as a buffer to backfill the water area of LRW storage reservoir. Cost estimates were provided based on the case study of reservoir V-17 capping (FSUE PA “Mayak"). It was demonstrated that adequate level of safety can be ensured given the use of the proposed amount of contaminated materials [9]. During the study, costs associated with the transportation of RW to the disposal facility site and of contaminated materials to reservoir B-17 were conservatively assumed to be the same and equal to 0.05 of the total RW management cost. RW packaging and treatment costs were taken equal to zero, since [9] considered the materials with the specific activity corresponding to the one VLLW. RW characterized with such an activity is allowed to be disposed of with no prior conditioning in accordance with the provisions of the law [1] and federal norms and rules in the field of atomic energy use [10].

When considering activity \#4, we will proceed from economic evaluations provided in article [11] demonstrating that the application of near-surface disposal concept for graphite RW allows to achieve tangible economic effect (cost reduction of up to 2 times).

Under this study, relevant variations of the performance indicator for each of the presented RW streams were considered, as well as relative changes of the performance indicator for the totality of the RW streams $(\delta E, \%)$ resulting from this measure. Table 1 summarizes the results of the evaluation covering the considered measures on the enhancement of RW management efficiency.

Based on the approximations applied, the greatest increase in efficiency is observed for measure 1 which is basically due to two reasons:

- zero value of USS RW performance considering this stream (lack of fundraising mechanisms to perform relevant activities addressing newly emplaced RW);

- high efficiency of activities on the conservation of storage facilities for non-retrievable RW (costs can be reduced by dozens of times if compared to the option suggesting waste retrieval and disposal in a centralized RWDF [12]).

Considering the activities associated with retrievable RW management, establishment of a purposedesigned RW DF for graphite RW disposal provides the biggest contribution.

One should note that relative contribution of various activities aimed at increasing USS RW performance indicator will depend on the composition of RW streams considered in the evaluation. Thus,

Table 1. Assessment of how individual measures can impact the USS RW performance

\begin{tabular}{|c|c|c|c|c|c|c|}
\hline Measure & $\frac{U H O_{i} A C_{i} \cdot \sum_{k} A_{k}^{i} \cdot P_{k}}{C \Pi_{i}}$ & $\begin{array}{l}\text { Sbefore, } \\
\mathrm{mln} \text { RUB }\end{array}$ & $\begin{array}{l}\text { Ebefore, } \\
m \ln \text { RUB }^{-1}\end{array}$ & $\begin{array}{l}\text { Safter } \\
\text { mln RUB }\end{array}$ & $\begin{array}{c}E_{\text {ofter }} \\
\mathrm{mln} \mathrm{RUB}^{-1}\end{array}$ & $\delta E, \%$ \\
\hline $\begin{array}{l}\text { 1. Inclusion of RW placed into facilities holding } \\
\text { non-retrievable RW into the financial model }\end{array}$ & $8.7 \mathrm{E}+02$ & $1.0 \mathrm{E}+01$ & 0 & $1.0 \mathrm{E}+01$ & $1.0 \mathrm{E}-01$ & $1.4 \mathrm{E}+02$ \\
\hline $\begin{array}{l}\text { 2. Segregation of accumulated RW when the waste } \\
\text { is retrieved for the purposes of its treatment and } \\
\text { transfer to disposal site }\end{array}$ & $5.1 \mathrm{E}+03$ & $1.5 \mathrm{E}+02$ & $6.7 \mathrm{E}-03$ & $1.3 \mathrm{E}+02$ & 7.7E-03 & $8.5 E+00$ \\
\hline $\begin{array}{l}\text { 3. Use of contaminated materials to perform conser- } \\
\text { vation of LRW storage reservoirs }\end{array}$ & $4.1 \mathrm{E}+02$ & $2.8 \mathrm{E}+03$ & $3.6 \mathrm{E}-04$ & $2.5 \mathrm{E}+02$ & $4.0 \mathrm{E}-03$ & $2.4 \mathrm{E}+00$ \\
\hline $\begin{array}{l}\text { 4. Establishment of a purpose-designed RWDF for } \\
\text { graphite RW }\end{array}$ & $6.0 \mathrm{E}+05$ & $2.2 \mathrm{E}+04$ & $4.6 \mathrm{E}-05$ & $1.2 \mathrm{E}+04$ & 8.3E-05 & $8.1 \mathrm{E}+01$ \\
\hline
\end{tabular}


for example, contribution of operations associated with segregation of accumulated RW to USS RW performance (measure 2) will grow, if this practice is extended to other facilities in addition to the waste storage facility at Beloyarsk NPP. As a first approximation, its influence will increase proportionally to the amount of RW accumulated at NPPs and subject to segregation.

\section{Prospects for the development of an approach allowing to assess the effectiveness of other nuclear legacy cleanup activities}

Various modifications of such an approach allowing to assess the effectiveness can have a fairly wide range of applications. The method described above has the potential for calculating the effectiveness of measures associated with the dismantlement of unused facilities, construction of safety barriers or reconstruction of nuclear facilities. In its essence, the main effect achieved through the implementation of such measures is attributed to the fulfillment of safety requirements established by legislation of the Russian Federation, in particular concerning prevention of radiation accidents and the release of radioactive substances into the environment.

The relevance of evaluations enabling to assess the effectiveness of measures on the management of nuclear facilities is considered to be extremely high due to the scale of activities and the limited financial and engineering resources available. In this regard, the task of optimizing the distribution of funds being allocated for different measures and prioritizing relevant activities should be addressed. Development of a sound approach allowing to address it will significantly accelerate the process of achieving the final safe state of the considered nuclear facilities. Therefore, timely analysis of the accumulated experience in the implementation of relevant measures with the focus placed on the most effective areas (with the maximum return showing the reduction of hazard indicator per unit of invested funds) will enable to develop optimal decommissioning strategies at various levels in the future:

- during the development of nuclear decommissioning concepts;

- during the development of a comprehensive local decommissioning strategy for an industrial site in general;

- during the development of plans regarding the measures to be implemented under federal programs.

Performance assessments also reveal the dynamics of changes in the quality of the implemented activities. It's believed that the existing knowledge and experience, integrated approach to project management, modern methods of data processing, computerization and digitalization of projects, risk and uncertainty assessments based on the simulation of potential future processes will significantly increase the efficiency of expenditures and distribution of resources.

The proposed performance evaluations may be also applied to elaborate the tasks on the financial and economic justification of decisions regarding the management of nuclear facilities, in particular, those concerning the selection of priority activities to increase the effectiveness of the implemented measures.

\section{Conclusion}

USS RW development under a setting suggesting the presence of partially contradictory interests of the stakeholders (national operator, RW generators, specialized organizations) requires an approach to be developed to assess the degree to which various measures can impact the overall performance of the system. Such estimates can be done using a method applied to calculate integrated hazard index which was previously successfully applied to plan nuclear legacy cleanup efforts, namely, to prioritize facilities and monitor work execution.

The proposed methodology was tested by applying it to particular measures aimed at increasing the efficiency of RW management activities with the following measures being selected as such:

- inclusion of RW held in storage facilities for nonretrievable RW into USS RW financial model;

- implementation of measures to reduce the volume of accumulated RW by means of waste segregation during its retrieval;

- use of contaminated materials to construct EBSs during the conservation of LRW storage reservoirs; - optimization of RW disposal system based on the case study suggesting the establishment of a nearsurface RWDF for graphite waste.

Effectiveness of the measures considered was compared (provided that these measures were to be implemented at individual sites). It was demonstrated that the inclusion of RW emplaced into facilities holding non-retrievable RW into USS RW financial model can be considered as the most promising option. Implementation of other proposals also resulted in a significant increase of RW management efficiency, especially considering the possibility of their scaling to other similar facilities.

In general, the proposed approach can be further developed to cover other activities relevant for nuclear legacy cleanup that requires numerical evaluations to assess the effectiveness of activities performed or to select priority measures allowing to increase the efficiency. 


\section{References:}

1. Federal'ny zakon ot 11 iulya 2011 g. № $190-F Z$ “Ob obrashhenii s radioaktivnymi othodami i o vnesenii izmenenij v otdel'nye zakonodatel'nye akty Rossijskoj Federacii”. [Federal Law of 11 July 2011 No. 190-FZ "On the management of radioactive waste and amending separate legal acts of the Russian Federation"].

2. Federal'nyj zakon ot 21 noyabrya 1995 g. № $170-\mathrm{FZ}$ "Ob ispol'zovanii atomnoj energii” [Federal Law of 21 November 1995 № 170 - FZ “On the Use of Atomic Energy”]. 3. Bolshov L. A., Linge I. I., Abalkina I. L. i dr. K voprosu ocenki ob'ema yadernogo naslediya $\mathrm{v}$ atomnoj promyshlennosti i na inyh ob'ektah mirnogo ispol'zovaniya atomnoj energii $\mathrm{v}$ Rossii. [On the issue of assessment of the volume of nuclear legacy in nuclear industry and at other facilities of peaceful use of atomic energy in Russia]. Yadernaya i radiacionnaya bezopasnost - Nuclear and Radiation Safety, no. 3 (73), 2014, pp. 3-13. (In Russian).

4. Bakin R. I., Biryukov D. V., Ilyushkin A. I. i dr. Ranzhirovanie istochnikov radiacionnogo riska. [Ranking of radiation risk sources] Preprint IBRAE № IBRAE-2014-07, 2014. (In Russian).

5. Biryukov D. V., Vedernikova M. V., Savkin M. N. i dr. Prakticheskie potrebnosti razvitiya metodologii analiz riska dlya zaklyuchitel'nyh stadij zhiznennogo cikla [Practical needs for development of risk analysis methodology for the final stage of lifecycle]. Radiaciya i risk - Radiation and risk, 2015, no. 2 , pp. 116-130. (In Russian).

6. Dorofeev A. N., Linge I. I., Samoylov A. A., Sharafutdinov R. B. K voprosu finansovo-ekonomicheskogo obosnovaniya povysheniya effektivnosti normativnoj bazy EGS RAO [Feasibility study on enhancing the efficiency of uss rw regulatory framework]. $R a-$ dioaktivnye othody - Radioactive Waste, 2017, no 1, pp. 22-31. (In Russian).

7. Abalkina I. L., Barchukov V. G., Bochkarev V. V., Vedernikova M.V., Dorogov V. I., Kochetkov O.A., Kryshev I. I., Linge I. I., Panchenko S. V., Savkin M. N., Utkin S.S. Nauchno-tekhnicheskoe posobie po podgotovke obosnovyvayushchih materialov dlya prinyatiya resheniya ob otnesenii radioaktivnyh othodov k osobym radioaktivnym othodam.[ Scientific and technical guide on prepration of justificatio materials for decision-making on regarding radioactive waste as special radioactive waste]. Version 2.0 IBRAE RAN, 2014, 157 p. (In Russian).

8. Ivanov V. K., Gorsky A. I., Korelo A. M., Maksyutov M. A., Tumanov K.A., Samojlov A.A., Biryukov D. V., Il'yasov D. F. Minimizaciya radiacionnyh riskov personala $\mathrm{V}$ situaciyah planiruemogo oblucheniya na primere vypolneniya rabot po likvidacii ob"ektov yadernogo naslediya [Minimization of radiation risks for personnel in planned exposure situations for examples of projects on nuclear legacy facilities decommissioning]. Radiaciya i risk $-R a-$ diation and risk. (Bulletin of the National radiation and epidemiologic register), 2017, Vol. 26, no. 4, 2 pp. 7-21. (In Russian).

9. Samojlov A. A., Boldyrev K. A. Podhody k optimizacii konservacii vodoema-hranilishcha V-17 [Approaches to optimization of conservation of V-17 storage pond]. Voprosy radiacionnoj bezopasnosti Radiation safety issues. 2019, no. 1 (93), pp. 25-35. (In Russian).

10. Federal'nye normy i pravila $\mathrm{v}$ oblasti ispol'zovaniya atomnoy energii "Kriterii priemlemosti radioaktivnyh othodov dlya zahoroneniya (NP-093-14)" [Federal codes and standards in the field of use of atomic energy "Criteria for acceptance of radioactive waste for disposal (NP-093-14)"]. Utv. prikazom Federal'noy sluzhby po ekologicheskomu, tekhnologicheskomu i atomnomu nadzoru ot 15 dekabrya 2014 g. № 572.

11. Dorofeev A. N., Komarov E. A., Zaharova E. V., Volkova A. G., Linge I. I., Ivanov A. Yu., Utkin S. S., Pavlyuk A. O., Kotlyarevskij S. G. K voprosu zahoroneniya reaktornogo grafita [On Reactor Graphite Disposal.] Radioaktivnye othody - Radioactive Waste, 2019, no. 2 (7), pp. 18-30. (In Russian). DOI: 10.25283/2587-9707-2019-2-18-30

12. Special radioactive waste / Edited by I. I. Linge. Moscow, LLC "SAM poligrafist" Publ., 2015. 240 p. (In Russian).

\section{Information about the authors}

Samoylov Andrey Anatolevich, Senior Researcher, Nuclear Safety Institute of RAS (52, Bolshaya Tulskaya St., Moscow, 115191, Russia), e-mail: samoylov@ibrae.ac.ru.

Ilyasov Damir Fatovich, Scientific Researcher, Nuclear Safety Institute of RAS (52, Bolshaya Tulskaya St., Moscow, 115191, Russia), e-mail: idf@ibrae.ac.ru.

\section{Bibliographic description}

Samoylov A. A., Ilyasov D. F. On the Issue of RW Management Efficiency. Radioactive Waste, 2019, no. 3 (8), pp. 36-43. DOI: 10.25283/2587-9707-2019-3-36-43. (In Russian). 